\title{
Erratum to: A phase I/II study of ofatumumab (GSK1841157) in Japanese and Korean patients with relapsed or refractory B-cell chronic lymphocytic leukemia
}

\author{
Yoshiaki Ogawa $\cdot$ Michinori Ogura - Tatsuya Suzuki $\cdot$ Kiyoshi Ando \\ Toshiki Uchida • Yukari Shirasugi • Kensei Tobinai · Je Hwan Lee • \\ Masazumi Kase $\cdot$ Koichi Katsura $\cdot$ Tomomitsu Hotta
}

Published online: 19 December 2013

(c) The Japanese Society of Hematology 2013

\section{Erratum to: Int J Hematol (2013) 98:164-170 DOI 10.1007/s12185-013-1393-x}

A published-ahead-of-print version of this article was made available online on 12 July 2013. It was subsequently determined that the reported drug concentration measurements were from a manner which deviated from the Standard Operation Procedures (SOP) in place at the time of sample analysis. This deviation involved an enzymelinked immunosorbent assay (ELISA) which was used for measurement of plasma ofatumumab concentrations in Study OMB112758, involving 45 samples on one specific

The online version of the original article can be found under doi:10.1007/s12185-013-1393-x.

Y. Ogawa $(\bowtie) \cdot$ K. Ando · Y. Shirasugi

Department of Hematology and Oncology, Tokai University

School of Medicine, Shimokasuya 143, Isehara,

Kanagawa 259-1193, Japan

e-mail: yoshioga@is.icc.u-tokai.ac.jp

M. Ogura $\cdot$ T. Suzuki $\cdot$ T. Uchida

Department of Hematology and Oncology, Nagoya Daini Red Cross Hospital, Nagoya, Japan

\section{K. Tobinai}

Department of Hematology, National Cancer Center Hospital,

Tokyo, Japan

J. H. Lee

Department of Hematology, Asan Medical Center, Seoul, Korea

M. Kase · K. Katsura

GlaxoSmithKline K.K, Tokyo, Japan

T. Hotta

National Hospital Organization Nagoya Medical Center,

Nagoya, Japan immunoassay plate among a total of 307 samples in this study. Re-measurement of these impacted samples was performed in compliance with the current SOP, and the pharmacokinetic parameters were re-calculated. The correct data and figure appear below. This substitution of data does not impact on any scientific findings and outcomes, logic of discussion and the conclusion of the manuscript. The authors wish to apologize to readers and editorial office for any inconvenience this might cause.

On the 5th page on line 4 in the right column, " $834 \mu \mathrm{g} /$ $\mathrm{mL}$ " should be " $832 \mu \mathrm{g} / \mathrm{mL}$ ".

On the 5th page on line 10 in the right column, "71, 1691 and $865 \mu \mathrm{g} / \mathrm{mL}$ " should be "69, 1670 and $865 \mu \mathrm{g} /$ $\mathrm{mL}$ ".

On the 5th page on line 11 in the right column, " $1524 \mathrm{~h} \mu \mathrm{g} / \mathrm{mL}$ " should be " $1506 \mathrm{~h} \mu \mathrm{g} / \mathrm{mL}$ ".

On the 5th page on line 12 in the right column, "200904 h $\mu \mathrm{g} / \mathrm{mL}$ " should be "200182 h $\mu \mathrm{g} / \mathrm{mL}$ ".

On the 6th page on line 27 in the right column, " $1691 \mu \mathrm{g} / \mathrm{mL}$ " should be " $1670 \mu \mathrm{g} / \mathrm{mL}$ ".

There are errors in Fig. 2. The correct version is given below.

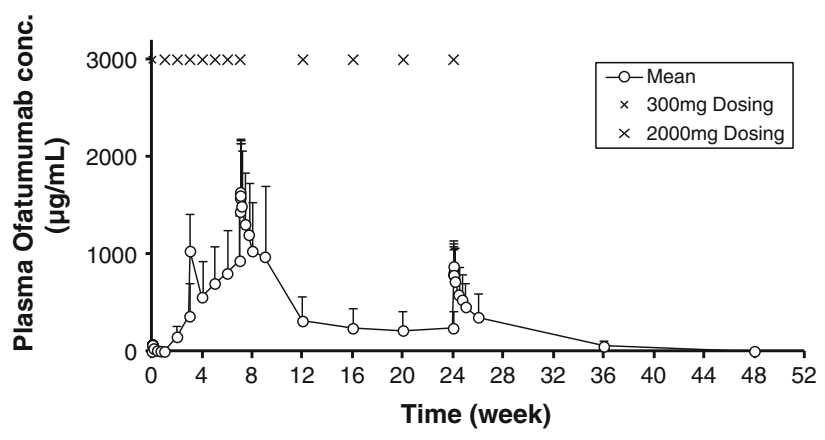

Fig. 2 Mean $(+\mathrm{SD})$ plasma concentration of ofatumumab-time plots 
There are errors in Table 6. The correct version is given below.

Table 6 Pharmacokinetic parameters of ofatumumab

\begin{tabular}{lccc}
\hline & Day 1 & Week $7^{\text {a }}$ & Week 24 \\
& $300 \mathrm{mg}(N=8)$ & $2000 \mathrm{mg}(N=8)$ & $2000 \mathrm{mg}(N=7)$ \\
\hline$C_{\max }(\mu \mathrm{g} / \mathrm{mL})$ & 69 & 1670 & 865 \\
& $(43-111)$ & $(1325-2106)$ & $(659-1136)$ \\
$C_{\min }(\mu \mathrm{g} / \mathrm{mL})$ & - & 832 & 122 \\
& & $(540-1283)$ & $(29-518)^{\mathrm{c}}$ \\
$\mathrm{AUC} C^{\mathrm{d}}(\mathrm{h} \mu \mathrm{g} / \mathrm{mL})$ & 1506 & 200182 & 216678 \\
& $(594-3820)$ & $(139285-287703)$ & $(114238-410979)$ \\
$t_{1 / 2}(\mathrm{~h})$ & 9.6 & 331 & 300 \\
& $(5.0-18.2)$ & $(224-491)$ & $(182-495)$ \\
$\mathrm{CL}(\mathrm{mL} / \mathrm{h})$ & 199 & 10.0 & 9.2 \\
& $(79-505)$ & $(7.0-14.4)$ & $(4.9-17.5)$ \\
$V_{\mathrm{ss}}(\mathrm{mL})$ & 3668 & 1334 & 3069 \\
& $(2325-5788)$ & $(929-1915)$ & $(2123-4437)$ \\
$\mathrm{MRT}(\mathrm{h})$ & 18.4 & 478 & 464 \\
& $(10.4-32.5)$ & $(333-686)$ & $(264-817)$ \\
\hline
\end{tabular}

Geometric mean (95\% confidence interval)

a After final (8th) weekly dose

b After final (4th) monthly dose

c $N=8$

${ }^{\mathrm{d}} \mathrm{AUC}_{0-\text { inf }}$ for day $1, \mathrm{AUC}_{0-168}$ for week $7, \mathrm{AUC}_{0-672}$ for week 24 